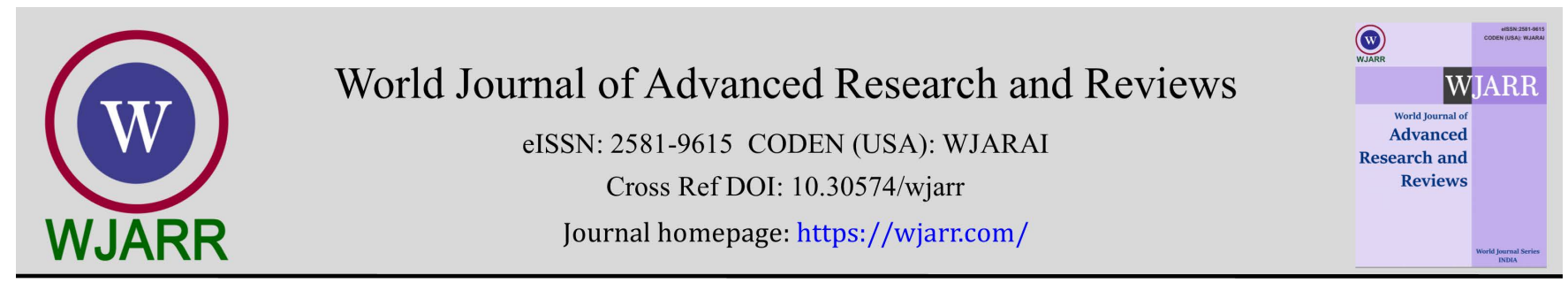

(REVIEW ARTICLE)

\title{
Entrepreneurship and dignity of man in Igbo Worldview
}

\author{
Peter Chukwuemeka Iloanya and John Nwanegbo-Ben * \\ Department of Philosophy Chukwuemeka Odumegwu Ojukwu University, Igbariam Campus \& Directorate of General \\ Studies Federal University of Technology, Owerri, Nigeria.
}

World Journal of Advanced Research and Reviews, 2021, 12(01), 047-055

Publication history: Received on 28 August 2021; revised on 30 September 2021; accepted on 02 October 2021

Article DOI: https://doi.org/10.30574/wjarr.2021.12.1.0498

\begin{abstract}
One of the greatest values in Igbo cosmology just like most people of the world is the dignity of the human person; and the parlance that there is dignity in labour is not strange to the Igbo people of Nigeria. In fact, it would be said that ndi Igbo are the people that understood the parlance better than every other people of the world. Consequently, an Igbo person does anything humanly possible to acquire the dignity bestowed by labour on humanity through genuine means he or she knows how.One will now wonder little why ndi Igbo engage in all sorts of enterprise excluding none. This is because they believe that it is in enterprise that man's dignity is haboured. Physically, among the factors that enhance man's dignity, wealth is the simplest and most visible that one can easily access; ndi Igbo believe that it is through ones enterprise that wealth can be created. Therefore, the paperseeks to consider analytically those enterprenual activities that ndi Igbo explore such as Igbaboi, Imuahia, olu aka and other entrepreneurial and apprenticeship system through which they ensure that wealth keep on circulating in their midst in other to ensure that man' dignity remains sacrosanct in Igbo cosmology.
\end{abstract}

Keywords: Entrepreneurship; Dignity of man; Igbo cosmology; Igbaboi; Imuahia; Apprenticeship

\section{Introduction}

Ndi Igbo all over the world are known to be enterprising and hardworking. This quality of being industrious is evident in the everyday life of the people. One must work hard in other to earn his living (Afigbo, 1972: 282-283). However, ndi Igbo are very hard working and enterprising not just because there is no food for a lazy person rather, they know that the prosperity of a people and dignity of the community is dependent on the individual efforts and hard work, since it is the individuals that make up a community. Ebigbo (2002) corroborates "The Igbos are hard workers, because they naturally believed in the philosophy that one must always be the architect of his or her own destiny. Therefore, they determined to work hard and succeed" (43). In other words, the personality and dignity that a people enjoy as far as ndi-Igbo are concerned are not far from the material wealth of the people akin to Marx opinion that economy is the pivot around which other sectors of the society revolve (Iloanya \& Anowai, 2006). Ndi-Igbo believe also that a person worth not his dignity without wealth among other things. Thus, "mmanwoke"-money-is at the root of this materialistic philosophy and has become the biggest benchmark for a well-endowed, successful and dignified personality (Ani Casmire, Ome \& Nwankwo, 2014: 398).

Ndi-Igbo due to their communal nature see everything from the communal perspective including dignity of the human person.Ani Casmir, Ome \& Nwankwo (2014), concur:

\footnotetext{
${ }^{*}$ Corresponding author: John Nwanegbo-Ben

Department of PhilosophyChukwuemeka Odumegwu Ojukwu University, Igbariam Campus\& Federal University of Technology, Owerri, Nigeria.
}

Copyright (C) 2021 Author(s) retain the copyright of this article. This article is published under the terms of the Creative Commons Attribution Liscense 4.0. 
The construction of the model Igbo personality starts with an adequate appreciation of the communal role of the individual in maintaining societal balance, peace, prosperity (wealth) and moral transparency. It is impossible to think of the individual as different from the community. There is a pre-existing metaphysical and social bond that inextricably links one to the other. The interests of the individual are concomitant with that of community. His aspirations, dreams and hopes for a better future and a fulfilled life are dialectically tied to the communal apron strings of what is good for the community (397).

The above assertion is in line with the idea that the Igbo man, primordially, is able to perpetuate his race as a result of his community-in-person values which propel and motivate him to strive to achieve and maintain self-respect, esteem, pride, sense of social shame, indignation and resentment for evil doing in the community (Ani Casmire, Ome \& Nwankwo, 2014: 402). Chinwuba \& Ezeugwu (2017) similarly held, "Igbo people believe in purposeful hard work, and personal effort filled with communal colouration... Because individuals make up the community that make up the society, the economic success of the individuals is also the economic success of the society at large." (2). Consequently, material dignity of man in Igbo cosmology is not an individual thing but rather a thing that sought to be done collectively and communally; hence the apprenticeship system that is observed among the Igbo people of Nigeria. More so, there is this belief system among the Igbo people that 'ofuosisiadiemeofia' a tree does not make a forest. Little wonder the practice of igbaboi, imuahia and other apprenticeship system prevalent among ndi-Igbo that are geared towards restoring the dignity of man in Igbo cosmology through entrepreneurship.

Thus, this paper is both practically and theoretically significant, in that it aids in exposing why ndi Igbo are enterprising and the means they apply in achieving their prosperity. It will also analyse some of the apprenticeship system which ndi-Igbo as a people applied to sustain their wealth. And the reason why every Igbo person struggles to ensure that he or she pertains in acquiring this dignity which wealth bestows on the individuals, hence, the reason for being enterprising.

\section{Conceptual Analysis}

\subsection{Entrepreneurship}

The concept entrepreneurship has nuances of meaning based on the area one is coming from. However, it could be seen as a process of setting up a business in which the risk and profit is suffered or enjoyed by an individual. Similarly, it is the willingness, capability and the inclination to develop, organize and run a business enterprise, along with any of its uncertainties in order to make a profit. According to Entrepreneur Hand Book (2021) "Entrepreneurship refers to the concept of developing and managing a business venture in order to gain profit by taking several risks in the corporate world. Simply put, entrepreneurship is the willingness to start a new business." Russell Sobel (2019), Entrepreneurship according to Chinwuba \& Ezeugwu, (2017) is self-employment of any sort, which bothers on continuously identifying, evaluating and taking advantage of business opportunities and initiating sustainable action to ensure success (1). It is as well understood as a search for profit based on innovation, creativity and efficient utilization of resources in a consistent cultural pattern, which is filled with vision and enthusiasm and is result driven. Finally, "entrepreneurship for the Igbo people incorporates every profit and goal-oriented strategies which they describe as Ibidoahia or Oru (starting an enterprise), Izuahia (business transactions), Imuahia (learning a trade), Imuoru (learning a craft or vocation), and Igbaosoahia (indulging in trick of marketing another's goods with his consent at a price that raises capital)" Chinwuba \& Ezeugwu (2017:1).

\subsection{Apprenticeship}

The apprenticeship system is a training and skill development initiative practiced all over the world and it has long been used to prepare workers to gain occupational skills in many countries (Lerman, 2012 in Ejo-Orusa \& Mpi, 2019). According to Ejo-Orusa \& Mpi (2019) apprenticeship allows a male or female (depending on the type of business), family or community member to spend time and work with another family or community member or in some cases, not necessarily a family or community member, usually a successful business man (entrepreneur). During this period of time, the apprentice receives mentorship and training from the businessman or craftsman (105). Alake (2018) contends that as part of the Igbo business culture, the established businessmen (the nurturer) in a town, street or locale has a responsibility to take-in teenagers and young adults (the apprentice) from their homes and give them informal business training and mentorship. For Crescent (2019) in Kanu (2019):

apprenticeship System is an unpaid business apprenticeship/incubator model that let people learn business from a master for a certain number of year (5-8) depending and at the end of their apprenticeship tenure, gets cash infusion and support to start their own business. There is no salary paid during the time of the apprenticeship tenure but meals, 
clothing and t-fare are provided for by the master. When the years of learning are over, the boy is as good as his master (62).

Apart from the above explanations and definitions, the meaning of apprenticeship abounds depending on the area one approaches it. But the central issue about apprenticeship is that a mentee is learning from the master.

\subsection{Dignity}

The term dignity has nuances of meanings. Etymologically however, it is from Latin word dingus or dingnitas meaning "due a certain respect or worthy of esteem and honour". It could be said to mean an inalienable worth or value which inhere in every human person; the quality of being worthy of esteem or honour and importance.Shell in Kraynak (2003) similarly holds that dignity and value are related and juxtapose each other. Dignity is observed as "an intrinsic value which expresses the worth of something in relation to something else" (58). To have dignity, therefore, is to have value that makes one (something) priceless, or without equivalent. It also refers both to a kind of deserving and to something deserved (Ezenwa, n.d: 14). ForReaders Digest Creative Illustrated Dictionary (1990) dignity refers to that which in a being or a person induces or ought to induce respect. It embraces any activity or concept that brings out the true nature of the human person and distinguishes mankind from all other beings in the universe. In the words of Maduka (2019) dignity consists in the quality, value, worth or importance attached or attributed to a person over and above other things (126). Rahner (1975), sees it as "the fact that a being has of its very nature a determined objective position within the manifoldness and heterogeneity of being which demands respect and protection as well as realization both in its relations to others and itself." (236)

\subsection{Man}

Man in this paper does not mean an individual sex rather it is as Ojoajogwu (2006) puts it "the Hebrew Adam, Latin Homo, Greek Anthropos or German Mensch". (109) "Man" in this work signifies man as humanity in general without distinction; "a being that is in existence like other existing beings but with different characteristics" (Ezenwa, n.d: 20). It implies the human person in general. Therefore, man could said to mean (homo phenomenon, animal rationale) a being of slight importance and shares with the rest of the animals as offspring of the earth, a common value (pretium vulgare) but man has in his understanding something more than they and can set himself ends... Man considered as a person ... is lifted up (erhoben) above all price, for as a person (homo noumenon) he is not to be valued merely as a means to the ends of others or even to his own ends, but as an end in himself; that is, he possesses a dignity by which he necessitates respect (Shell, 2003: 65). For Metuh (1987) the human person (man) "is a life-force in vital relationship with other life forces in the universe (185). Man Gyeke (1992) affirms "is a being who is inherently and to the core communal and who is entrenched in social relationship and in no way as an isolated individual who acts alone" (104). Finally, this paper sees man as a being of highest value with a rational nature.

\subsection{Dignity of Man}

The concept man's dignity or dignity of man is a complex one. This is because what constitute man's dignity in a clime may differ from what amounts to it in other clime.Younkins (2012) in Ani, Ome \& Nwankwo (2014) aver, "Human (man) dignity, though a universal concept, has cultural correspondences in all indigenous communities of the world" (402). This is because a lot of people approach it with different interpretations and meanings, and under different contexts. Man's dignity is a universal value and concern which is used often in moral, philosophical, legal, social and economic discourses. But for our purpose here it will be said to mean the values cherished by a man in his community as "a manin-community". The above meaning implies that it is the people or the society that confers dignity on an individual just as was mentioned elsewhere in the paper. Hence, the dignity of man could be said to be anything attached to the man that indicates the value, worth and respect attached to him/her and because of the higher value humanity has against other beings. For Ezenwa (n.d), the term, "human (man's) dignity" indicates an expression of appreciation of the importance of the individual which as an attribute is meant to be inherent in every human person (man), and in essence, a fundamental value of every human being (man) (15).

\subsection{Igbo}

Igbo is both a language and a tribe in Nigeria. However, this paper will give attention to Igbo as a tribe. Thus, Igbo people according to Kanu (2012) are a single people even though fragmented and scattered, inhabiting a geographical area stretching from Benin to Igala and Cross River to Niger Delta. Chimakonam and Ogbonnaya (2015), aver that ndi Igbo are found in South-eastern Nigeria. They are a large ethnic group in the West African sub-region (271). They are occupying Agbor, Kwalle (West Niger Igbo), Ahoada, Diobu, Umuabayi (Port Harcourt), Arochukwu, Afikpo, Isiagu (Abakaliki Area), Enugwu-Ezike (Nsukka Area), Abo (West Niger Igbo)" (Onwuejeogwu, 1980: 8). This means that the Igbo occupy the entire Anambra, Imo, Abia, Ebonyi and Enugu States and parts of Rivers, Bayelsa and Delta States of 
present-day Nigeria. Ndi Igbo are a people known for their high dedication to duty resulting in their belief that in whatever field of endeavourthey are found they must remain achievers. They arecultured in doing things in a proper or universally accepted manner. Inother words, they are bestowed with pure sense of standardism.

All over the world they are known as being ambitious for the fact that they are always at the top or ahead of others in every field of live. The Igbo people among many other things are highly persevering, they struggle to make end meet. One will wonder little why they are very enterprising wherever they are and successful. They are extra resilient to retrogressive factors of life. No matter the ups and downs in their struggle to survival, Igbo people believe that giving up is not the best, so the end determines the means (Ani, Ome \& Nwankwo, 2014: 399-400). Finally, ndi Igbo are people that are industrious, enterprising, successful, resilient and above all human investors and nation builders.

\section{Distinction between igbaboi and Imuahia}

The concept of Igba boi and imuahia are two words that are always mistaken by so many people to mean one and the same under Igbo apprenticeship system, this is because the both are systems or kinds of informal and unstructured training programme scheduled for an agreed period of time which a person undergoes in order to acquire a desirable aspect of entrepreneurship knowledge (Ejo-Orusa\&Mpi, 2019: 105). The both have to do with learning-by-example in its purest form where the apprentice gets raw, real life and practical cut-throat business education. In the both system of apprenticeship, during the training period, the apprentice develops entrepreneurship skill and learns all the intricacies involved in the business such as supply-chain management, quality control, marketing and dealing with customers, forecasting, human relations, book keeping and accounting, negotiation skills, inventory control and analysis and opportunity recognition and utilization (Ejo-Orusa \& Mpi, 2019: 106). In the both aspects of apprenticeship system, there is usually no established curriculum, formal learning procedure or pedagogies and so the apprentice learns from or through observation, imitation, and in some cases, trial and error. Usually, the apprentice learns on the job by direct instruction (Adekola \& Ezekiel, 2013). Therefore, the extent to which the apprentice will learn will be dependent on the capacity and management style of the master/mentor on the one hand and the learning capacity and drive of the apprentice on the other. But in as much as they are closely related, they are not the same. Iwara, Amaechi \& Netshandama (2019) corroborates, while all types (of apprenticeship system) are geared toward the transfer knowledge of entrepreneur skills, they differ in approach.

However, when it comes to imuahia there is an agreement whereby the apprentice who is either learning a trade or handiwork (craft) pay the master a certain fee to enable him learn a particular trade or handiwork (craft) which spans for a period of time (between 3 months to 3 years or more). Iwara, Amaechi \& Netshandama (2019) concur, unlike the Igba-boi/IgbaOdibo where a mentee will be tutored for free for a period of pre-agreed years, in the ImuOru/ImuOruaka and ImuAhia types tutorship are paid for by the mentee or mentee's parents/sponsors. Under Imuahia apprenticeship system the trainee in most cases does not live with the trainer or his master. The apprentice comes most a times from home away from his master. He/she does not feed from the master and the master does not cater for any of his/her needs such as accommodation, transportation costs (where necessary), feeding and clothing i.e. physiological needs (Ejo-Orusa\&Mpi, 2019: 106). The apprentice under this type of apprenticeship system may not be regular to work or trade. He/she decides on the day to come and when not to come. The trainee cannot be sent home at will by the master as it is in the case of igbaboi and there is no settlement by the mentor at the end of the learning period as it is in the case of igbaboi whereby the master or the mentor is expected to settle the apprentices at the end of agreed period.

Then in the case of igbaboi the apprentice does not pay his master to learn his trade or handicraft. The apprentices in most cases are under probation for 3 months after which an agreement will be reached that he/she will serve the mentor for specific number of years. The years of services or learning a particular trade or craft spans between 3 to 7 years. "Depending on the age, academic qualifications of the apprentices, learning capacity and of course the nature of the business, trade or craft. During this period, the apprentice learns the trade of his/her master and also receives mentorship" (Ejo-Orusa \& Mpi, 2019: 106). In the case of igbaboi, according to Ejo-Orusa and Mpi (2019) though the apprentices are often not paid, they are provided accommodation, transportation costs (where necessary), feeding and clothing (ie physiological needs) (106).Under Igbaboi apprenticeship system apart from learning the trade or handicraft the trainee living with his mentor assist in other house and domestic chores like fetching water, cooking food for his/her mentor, washing dishes and cloths, engaging in school run of the children and some other duties as the need arises. Nwaboi in most cases has no decision of his/her own; whatever the master or the mentor decides is the final. In fact Igbaboi is a quasi slavery; the only different there is that there is hope of being free after an agreed period of time which is not sacrosanct. The most interesting and unique part of Igbaboi apprenticeship system is that unlike imuahia, at the end of this traditional business school and service which the mentor performs the "settlement". This comprises of aiding the apprentice financially and otherwise in starting his/her own business or vocation based on the earlier agreement 
with the apprentice's family. Once this is done, the apprentice (Boyi) is now on his own, free from the mentor. Most of the apprentices often join their mentors at an early stage (Chinwuba \& Ezeugwu 2017: 21).

\section{Why the interest in entrepreneurship among ndi-Igbo}

Ndi-igbo are a people of value. They hold man in a very high esteem; in fact the human person for them is at the center of all things that there are. Ezenwa (n.d) corroborates:

The Igbo people have a culture that values the dignity of the human person; a dignity that implies a new humanism, where man is defined before all else by his/her responsibility to his/her brothers/sisters. Thus the human person is at the centre of every activity, and the maintenance of this value of his/her dignity is that which should interest all. It serves as a common bond that brings the people together and unites them as an entity for the maintenance and progress of each other. This value and the dignity attached to it is enshrined within the cultural setting of the people, becoming part and parcel of the people's cultural norms and providing the setting for effective realization of each other (18).

Therefore, the human person ought to be dignified. However, the dignity that a person enjoys, from Igbo person's perspective must come with a prize; the prize of hard work. Since hard work is the conveyor of dignity in Igbo cosmology every Igbo man sees it as a thing of value; an objective value at that. It is an objective value in that it is seen and guided by laws and customs of ndi-Igbo. Ezenwa (n.d.) affirms, "Among Igbo people hard work and industry are highly cherished and esteemed. These are characteristic values that are traditionally associated with them. This places food and other valuables on their table of life"(51). Egwu (1998), corroborates, "The Igbo are noted from their activity, their persevering effort in pursuit of their objectives, they are always meaningfully occupied in one useful activity or the other. This is in line with the assertion that there is dignity in labour" (46). The enterprising nature of ndi-Igbo is hinged on this belief.

Just like dignity, entrepreneurship is highly cherished among ndi-Igbo because for them it is precious activity in human lives which form the essential ingredients that make up life's joys and inspirations. It is what appeals to ndi-Igbo which supply a need, satisfy a desire, arouse an interest, stimulate an emotion, provoke a response, motivate a deed and draw communal approval and respect. It is therefore that which makes someone to be cherished and apportioned a special type of property, rank, dignity and character in the community.

Ndi-igbo are of the opinion that entrepreneurial value can influence attitudes and behavioural patterns, like the life pattern one cherishes; and serves as an influence on the individual. The Igbo understands entrepreneurship as a potent economic force, and a core element in the development efforts of an individual and the nation at large (Chinweuba \& Ezeugwu, 2017:1). For Igbo people entrepreneurship serves as a changing and challenging factor in one's life. It positively expresses what is good, beneficial, important, and constructive. It also answers to some extent the question of why Igbo people do what they do and relate to things the way they do. It deals with what are of relevance to Igbo people. More so, they engage into entrepreneurship in an attempt to satisfy their deep-rooted need and interest to be truly Igbo and economic reliant personalities (Chinweuba \& Ezeugwu, 2017:1). The Igbos believe in maintaining legacies in business. This attempt at maintaining legacies of business success account for efficiency and expertise in entrepreneurial programmes. ( Nwanegbo-Ben, J \& Ozoigbo B.I. 2021:37)

Furthermore, in Igbo cosmology the ultimate belief is that a person or being is human because she/she is worth more in quality and essence than other (beings) things (Mmaduka, 2019: 128). Yet, in Igbo land the human person's dignity and honour among other things are measured by ones material acquisition in the community. In this genuine acquisition is contained respect and dignity that an average Igbo person enjoys. The Igbo people are conversant with the statement 'ego bummanwoke' meaning that wealth is the dignity of a man. There is also another saying that 'onyenwe ego, onweeumunna' meaning when one has wealth he will be recognized by his kinsmen. On the other hand the titled institutions promote individual industry with the prestige, power, and authority attached to it." (Anyanwu, 2004: 35) The titles result from their hard earned and honest labour, therefore, many aspire to be titled individuals to share in the respects, rights and privileges that go with the title.

In addition as Chinweuba and Ezeugwu (2017) opine "in the ontology of Igbo people of Nigeria, life is a continuous struggle towards socio-economic excellence and perfection. Economic struggle is therefore of paramount importance because Igbo society has no room for failures and able bodied idlers that merely exist, depending on others for sustenance" (3).All these saying are the pointer that an Igbo man's dignity is not divorced from his material acquisition. However, this wealth talked about in Igbo cosmology that attracts dignity are not just gotten by all means. In other words it is not every type of wealth that attracts dignity in Igbo cosmology but rather the type that is made through the right means; that is the type that is called 'ego juluoyi' (cool money or genuine wealth). Chinwuba \& Ezeugwu (2017) 
concur, although, the Igbo cherish economic achievements, they do not value every kind of wealth. Thus, wealth acquired through dubious means and circumstances does not earn intrinsic respect in Igbo land. As such, wealth acquisition is expected to tow the means of hard work, integrity and honesty (3).

\section{Labour: the bearer of dignity in Igbo world-view}

It is argued that personhood (human dignity) is not what one has to work for or acquire. It is rather inherent in one's ontological nature. Thus, whether the community recognizes it or not, a person remains a person because of the possession of intrinsic worth or value over other creations. Gyekye (1992) similarly, presents a normative view of personhood from the Akan perspective. According to him, though a person may be described as communitarian by virtue of being born into an existing community, yet such a community does not determine his humanity. Instead he/she remains a person by virtue of the morality of his/her conduct. In other words, personhood is for Kwame (1992), defined in terms of moral qualities. Kwame's normative conception of the human person appears to be lopsided as it does not consider other essential aspects of the personhood of a person (109-110). Thus, it is argued that personhood is the intrinsic ontological virtue of a person that distinguishes him/her as a human being. Being human is an expression of the intrinsic, ontological worth of someone over other beings.

But facing the fact this research believes that Mmaduka is trying to sound ideal. In reality even from time immemorial ones acquisition is among the things that accrue dignity and respect to him. Ndi Igbo being a pragmatic and existential society believe that one's hand work and wealth accrue such dignity that is why they all put their hands on deck to see that he/she enjoys it.Chinweuba \& Ezeugwu, (2017) corroborate, "The Igbo entrepreneurial worldview which is the pervasive unified socio-economic picture of their cosmos is the main catalyst behind their socio-economic rhythms in the universe" (2).This reality insisting that the desirability of starting an enterprise is strongly influenced by one's worldview (Uchehara, 2009:43) affirms. Significant part of this worldview therefore is Igbo culture of praise and recognition for well deserved wealth (Chinweuba \& Ezeugwu, 2017: 2). This tradition of encomium is discernible even in Igbo religious beliefs, rites, rituals, festivals, folklores and myths (Oguejiofor, 2009). Chinweuba \& Ezeugwu, (2017) corroborate:

In fact, the Igbos views wealth as a means of gaining social prestige and acquiring social befitting rank.This stems from Igbo cosmological view of human existence encapsulated in their proverb Nwatakwochaa aka,osoroOkenyerienri(A child that washes his hands dines with the Elders). Based on this worldview, the traditional Igbo people flaunt their expanse lands, large farms and abundant harvests, their large compounds marked by numerous houses and peopled by wives, offspring and dependants which are the fruits of their entrepreneurial efforts. This accords them recognition and titles from the society such as $\mathrm{Ozo}, \mathrm{Oba}$, Ichie,Ochiliozuo, Osirioha, Ogbuehi, to mention but a few. It then means that one is judged worthy of attaining the social rank in Igbo context based on his large wealth and philanthropic deeds felt by the community. Most importantly, this tradition serves as an incentive towards purposeful entrepreneurship in the Igbo society. Hence for the Igbos, entrepreneurial success is not just a choice but a must (2).

Chinwuba \& Ezeugwu (2017) continue "Igbo culture which stems from their worldview lays much emphasis on it as a mark of distinction in the society. In addition to the cosmic socio-economic wellbeing, riches and material achievements, wealth for the Igbos have a very important eschatological implication"(2). Thus, in Igbo metaphysical understanding of existence, no one who dies poor (Enwenta, enweimo-the miserable poor) deserves a place among the ancestors (Oguejiofor, 2004 in Chinwuba \& Ezeugwu 2017: 2).

As such, one's honest acquisition accords him admission into the club of the Ancestors in the afterlife, and even guarantees him reincarnation. This eschatological reality stemming from their worldview is indeed part of the drive behind the Igbo ambitious and competitive entrepreneurship. No wonder, the Igbos reflect entrepreneurship and its fruits even in their naming culture. Thus, names like Oruamaka(work is good), Oruoma(good work), Oruebube(glorious work), Orunna (work of the father), Ifeadigo(wealth is available), Ubaka(wealth is greater), Ubanozie(wealth has taken the proper position), etc abound among the Igbos, pointing to their entrepreneurial and acquisition attitude. In fact, in order to belong to this cultural recognition, admiration and reward, Igbo people display all the economic initiative, characteristics of hardworking and astute trading (Dioka, 1997 in Chinwuba\&Ezeugwu 2017: 2).

As already mentioned in the introductory part of this paper ndi-igbo are communal in nature, there it is the community that determines ones level of dignity and respect in an area in which a person is a member and lives. Menkiti (1984) avers (dignity) personhood is something which has to be achieved, and not given simply because one is born of human seed" (172). The implication of Menkiti's assertion is that, the self or personal identity which an individual comes to possess as a human cannot be made sense of, except by reference to collective consciousness. The above assertion may 
sound unpalatable for people that see dignity as an intrinsic right of every man but the fact remains that there is a price for everything one enjoys including dignity.

The saying 'nwatakwocha aka osoroogaranyarienri' (when a child washes his hands he dines with the elders) is a pure indication of the belief in Igbo cosmology that wealth can in actual sense bring dignity to an individual. One will wonder little why most entrepreneurial initiatives, commercial centers, and structures in major Nigerian cities and the world at large are managed by the Igbo people. Furthermore, among ndi-Igbo, Ezenwa (n.d) coincides:

The exceptionally hard working and industrious people are spotted and rewarded in the community. This though an honour spurs many to work hard and to be honoured and appreciated as well. This increases productivity and reduces laziness and its concomitant negative effects against others. In the area of business, trade and education, in Nigeria Igbo people seem to dominate the scene. This is attributed to their hardworking nature (52).

The above assertion drives an average Igbo man into entrepreneurship because without wealth, as ndi Igbo believe one cannot enjoy full dignity and respect. And unless one enjoys such dignity and respect one is never fulfilled and actualized individual. Moreover, there is no other means of acquiring this wealth that bestows dignity and respect if not through labour or enterprise; hence, ndi Igbo see labour as the harbinger of dignity.

\section{Conclusion}

The quest for ndi-Igbo to uphold their dignity and dignity of man generally has driven them into many entrepreneurial activities. They believe that material wealth has a lot to contribute to the respect a person/ people enjoy. This is evidenced in their being everywhere from Ghana to China, from America to Australia and from Europe to anywhere that man can be found on the surface of the earth in pursuit of material wealth. They view economic achievement as a bondage that calls for higher achievements, respect and man's dignity. According to Chinweuba \& Ezeugwu (2017), "This existential philosophy underlies socioeconomic struggle and determination. As such, the Igbo hardly give up on life. He believes in his persistent mental and physical strength and the fact that honest effort yields meaningful economic gain. His concern is sustainable conducive environment that enhances socio-economic creativity" (24); which by implication attracts respect, prestige and every other paraphernalia that attracts and accrues respect to an individual and a people. Furthermore, high regard for dignity of man in Igbo cosmology has made them to violate every negative circumstantial factors like: illiteracy, poor background and other limiting factors rather they constitute reasons and serve as strength to achieve entrepreneurial success which they believe accompany respect and dignity of man.

\section{Compliance with ethical standards}

\section{Acknowledgments}

We wish to acknowledge all sources used to buttress our discussion on Entrepreneurship as a means of development and possible eradication of poverty in Nigeria.

\section{Disclosure of conflict of interest}

No conflict of interest statement.

\section{References}

[1] Adekola G, Ezekiel S. Traditional apprentice ship in the old Africa and its relevance to contemporary work practices in modern Nigerian communities. British Journal of Education, Society \&Behavioural Science. 2013; 3(4): 101-134.

[2] Afigbo AE. The Warrant Chiefs; Indirect Rule in Southern Nigeria. 1972; 1891-1929.

[3] Alake M. The Igbo apprenticeship system that builds wealth and started the incubation system. International Journal of Advanced Research in Management and Social Sciences. 2018.

[4] Ani Casmir KC, Ome E, Nwankwo A. Re-Examination of Igbo Values System, and the Igbo Personality: A Kantian and African Comparative Perspective. Open Journal of Philosophy. 2014; 4: 397-403.

[5] Anyanwu CCU. The Rites of Initiation in Christian Liturgy in Igbo Traditional Religion. Peter Lang, Frankfurt am Main. 2014. 
[6] Chimakonam JO, Ogbonnaya LU. A Conceptual and Contextual Meaning of Mmadu. in the Igbo Reality Scheme. Further Contribution to URAM Igbo Studies. 2015; 3-4: 268-285.

[7] Chinwuba GE, Ezeugwu EC. The Ontological Foundation of Igbo Entrepreneurship: An Analytical Investigation. Journal of Philosophy, Culture and Religion. 2017; 33: 17-24.

[8] Crescent. in Kanu, I.N. (2019): Igwebuikeconomics: The Igbo Apprenticeship System for Wealth Creation. African Journal of Arts and Humanities. 2019; 5(4): 56-70.

[9] Dioka JC. Inter-Group Relations among Nigerian Communities. In A. Osuntokun \& A. Olukoju (ed.), Nigerian Peoples and Culture, Ibadan: Davidson Press. 1997.

[10] Ebigbo C. The Igbo Lost Worlds. 2002 Iguaro Igbo Heritage Lecture. Enugu: Ezu Bks Ltd. 2002.

[11] Egwu R. Igbo Idea of the Supreme Being and the Triune God, Echter Verlag Würzburg. 1998.

[12] Ejo-Orusa H, Mpi DL. Reinventing The 'Nwaboi'apprenticeship System: A Platform For Entrepreneurship Promotion In Nigeria. International Journal of Advanced Research in Management and Social Sciences. IJARMSS. 2019; 8(9): 98-130.

[13] Entrepreneur Hand Book. What is entrepreneurship? 2021.

[14] Ezenwa CP.(n.d.). The Value of Human Dignity: A Socio-Cultural Approach to Analyzing the Crisis of Values among Igbo People of Nigeria. (Doctoral Dissertation).

[15] Gyekye K. Person and community in African thought. In Wiredu K and Gyekye K, (ed.). Person and community: Ghanaian Philosophical Studies, I. Washington D.C: Council for Research and Values. 1992; 101 - 122.

[16] Iloanya C, Anowai EC. Marxist Philosophy: a Perusal. Onitsha: Bookpoint Ltd. 2006.

[17] Iwara IO, Amaechi KE, Netshandama V. The Igba-boi apprenticeship approach:arsenal behind growing success of Igbo entrepreneurs in Nigeria. Ubuntu: Journal of Conflict and Social Transformation. 2019; 8(1): $227-250$.

[18] Kanu IA. Igwebuikeconomics: The Igbo Apprenticeship System for Wealth Creation. African Journal of Arts and Humanities. 2019; 5(4): 56-70.

[19] Kanu IA. The concept of life and person in African anthropology. In E. Ezenweke and I. A. Kanu (Eds.). Issues in African traditional religion and philosophy. 2012; 61-71.

[20] Kanu IA. Towards an Igbo Christology. In E. Ezenweke and I. A. Kanu (Eds.). Issues in African traditional religion and philosophy. 2012; 75-98.

[21] Kraynak R, Tinder G. (Eds.), In Defense of Human Dignity, University ofNotre Dame Press. 2003.

[22] Lerman RI.Can the United States expand apprenticeship? Lessons from experience.IZA Policy Paper, No. 46.2012.

[23] Maduka E. A Critical Exposition of Madukakism as a Theory of Being Human inContemporary Africa. Sociology and Anthropology. 2019; 7(3): 126-131.

[24] Menkiti IA. Person and community in African traditional thought. In Wright R. (ed.). African Philosophy: An Introduction. 2nd ed. New York: University Press of America. 1984; 170 - 80.

[25] Metuh EI. Comparative Studies of African Traditional Religion. Onitsha: Imico Pub. 1987.

[26] Mpi DL. Encouraging Micro, Small and Medium Scale Enterprises (MSMEs) for Economic Growth and Development in Nigeria and other Developing Economies: The role of 'the Igbo apprenticeship system'. The Strategic Journal of Business \& Change Management. 2019; 6(1): 535-543.

[27] Neuwirth R. The Age-old Sharing Economics of Africa - and why we should scale them. TED Talk. 2018.

[28] Nwanegbo-Ben J, BI Ozoigbo. Entrepreneurship and the "Cubana Principle" As the Basis of Igbo Cosmology. In Journal of Humanities and Social Policy. 2021; 7(1).

[29] Oguejiofor JO. African Philosophy and the function of socio-political criticism: A Skeptical Consideration. Uche Journal of Philosophy. University of Nigeria, Nsukka. 2004; 10: 23-39.

[30] Oguejiofor JO. Is African Worldview Responsible for the African Predicament? Uche Journal of Philosophy, University of Nigeria, Nsukka. 2009; 15: 1- 13.

[31] Ojoajogwu NO. Social and Cultural Identity of an African Society. IKO- Verlag für Interkulturelle Kommunikation Frankfurt am Main. 2006. 
[32] Onwuejeogwu A. An Igbo Civilization: Nri Kingdom and Hegemony. London: Ethiopia Publishing Corporation. 1980.

[33] Rahner K. Theological Investigations. Vol. II. London: Darton, Longman and Todd. 1975.

[34] Readers Digest Creative Illustrated Dictionary. Readers Digest Asso., Ltd., Guinnes Pub. Ltd., London. 1990.

[35] Russell Sobel. Entrepreneurship https://www.econlib.org/library/Enc/Entrepreneurship.html. 2019.

[36] Shell S, Kraynak R, Tinder G. (Eds.), In Defense of Human Dignity, University ofNotre Dame Press. 2003.

[37] Uchehara FO. Integrated Approach to Entrepreneurship Studies. Onitsha: Feros Prints \& Co. Ltd. 2009; 43.

[38] Younkins E. Dignity Demystified. https/ www.leQuetoecoiseLibre.Com. 2012. 